\title{
Identification of Factors Impeding the Spread of Jatropha Cultivation in the State of Chiapas, Mexico
}

\author{
Takayuki Ando ${ }^{1}$, Atsushi Tsunekawa ${ }^{1}$, Mitsuru Tsubo ${ }^{1} \&$ Hajime Kobayashi ${ }^{2}$ \\ ${ }^{1}$ Arid Land Research Center, Tottori University, Tottori, Japan \\ ${ }^{2}$ Faculty of Agriculture, Tottori University, Tottori, Japan \\ Correspondence: Takayuki Ando, Arid Land Research Center, Tottori University, Tottori, Japan. \\ Tel: 81-857-23-3411. E-mail: andota@alrc.tottori-u.ac.jp
}

Received: November 19, 2012 Accepted: December 7, 2012 Online Published: December 15, 2012

doi:10.5539/sar.v2n2p54

URL: http://dx.doi.org/10.5539/sar.v2n2p54

\begin{abstract}
The state government of Chiapas in Mexico is promoting the cultivation of jatropha by farmers as a source of biofuel, with the first harvest expected in 2012. However, despite the fact that the planted jatropha has now reached the harvesting stage, no reports exist on the current status of jatropha cultivation in Chiapas or on issues related to cultivation. We accordingly conducted a study aimed at ascertaining the current status of jatropha cultivation and identifying factors impeding its spread. For the study, we conducted a questionnaire survey among 88 farmers of 7 villages located within 3 municipalities, and also interviewed them. Our study pointed to 2 key factors causing the abandonment of jatropha cultivation, namely the failure of farmers to receive ProArbol payments as financial assistance for cultivation, and damage caused to jatropha roots by gophers. Pest/disease outbreaks, lack of technical assistance, lack of trust for extension workers and distrust for the project were also obstacles to the spread of jatropha cultivation.
\end{abstract}

Keywords: agricultural extension worker, gopher, Jatropha curcas L., obstacles, pest

\section{Introduction}

Jatropha is a drought resistant plant that has been increasingly cultivated as a source of biofuel that does not compete with food production (Heller, 1996). In developing countries, jatropha cultivation has also been promoted as a new means for poor farmers to boost their incomes (Brittaine \& Lutaladio, 2010).

Jatropha is a native of Mexico and other parts of Central America, and has traditionally been used in Chiapas as hedging (Zamarripa-Colmenero et al., 2009; Ruíz-Valdiviezo et al., 2010). The state government of Chiapas drew up a biofuel production policy in 2007 as a means of helping family farms in rural areas where poverty levels were high to boost their incomes by growing jatropha as a new cash crop that would also contribute to environmental conservation through its use as a source of biofuel (Gobierno del Estado de Chiapas, 2007; Vanegas-Cubillos, 2012). To promote the cultivation of jatropha, the state government imported seeds from India and provided farmers with both seeds and seedlings. As a result, jatropha cultivation by farmers in Chiapas began in 2008 (Skutsch et al., 2011; Valero-Padilla, Cortina-Villar, \& Vela-Coiffier, 2011). CONAFOR (National Forestry Commission, an agency in Mexico's central government) simultaneously started to disburse the first installment of a 2-installment payment of 6,310 pesos per hectare as financial assistance for jatropha cultivation under the government's ProArbol forest conservation and restoration program (Skutsch et al., 2011). The state government of Chiapas required farmers wanting to cultivate jatropha to form into groups under the auspices of a representative organization named the Bioenergy Society Union of Chiapas (USB) that was established in 2008. USB is responsible for instructing farmers in jatropha cultivation, processing applications for ProArbol payments, and such like (Arellanes-Caballero, 2008).

In Chiapas, the jatropha planted in 2008 was ready to harvest in 2012. The state government set up 4 collection points respectively in the municipalities of Villa Corzo, Parral, Acala, and Cintalapa, and began to buy up jatropha fruits and seeds. It also built a jatropha seed oil mill in Cintalapa in 2012 (Gobierno del Estado de Chiapas, 2012a), and plans to produce biodiesel using a plant in the city of Tapachula from this jatropha oil as fuel for 94 public buses operating in Tuxtla Gutiérrez and Tapachula Cities in Chiapas (Gobierno del Estado de Chiapas, 2012b; Green fuels, 2012). 
The ground has thus been laid for completion of the supply chain from cultivation to consumption in Chiapas. Sustaining this supply chain of course requires continued cultivation of jatropha, but Valero-Padilla et al. (2011) report that some farmers in Chiapas abandoned jatropha cultivation within 1 year of start of cultivation. A study conducted in southern India also reports that $85 \%$ of farmers who started to cultivate jatropha had abandoned the endeavor (Axelsson, Franzén, Ostwald, Berndes, \& Ravindranath, 2011). Because the cultivation of jatropha by family farms in Chiapas has only just reached the harvesting stage, no reports as yet exist on the current status of jatropha cultivation up to harvesting or on problems associated with the spread of jatropha cultivation. We accordingly conducted a study on family farms that have abandoned jatropha cultivation or downsized the area under jatropha cultivation, as well as farms that are continuing to cultivate jatropha, with the aim of ascertaining the current status of jatropha cultivation in Chiapas and identifying factors impeding the spread of cultivation and conditions required for sustained cultivation of jatropha in Chiapas.

\section{Method}

\subsection{Selection of Villages and Farmers for the Study}

We selected 7 villages located in the municipality of Villa Corzo (where, according to Arellanes-Caballero [2008] the extent and number of farmers engaging in jatropha cultivation from the first year of 2008 was highest) and 2 neighboring municipalities (Villaflores and La Concordia), enlisting the cooperation of 88 farmers (45 of whom were still cultivating jatropha, and 43 of whom had abandoned cultivation) for the study, which required them to fill out a questionnaire and sit for an interview.

\subsection{Questionnaire and Interview}

Study participants in each village were asked to come to their village's community center to fill out a questionnaire and sit for an interview to supplement the questionnaire. Participants were required to provide responses on a scale of 1 to 5 for all questions other than those requiring the entering of numerical data such as area under cultivation.

\subsection{Statistical Analysis}

We used the chi-square-test to compare responses between the villages. IBM SPSS Statistics ${ }^{\circledR}$ Version 20.0 was used for the statistical analysis.

\section{Results and Discussion}

\subsection{Outline of Surveyed Villages and Jatropha Cultivation}

We provide an outline of the surveyed villages in Table 1 and an outline of farmland and jatropha cultivation in Table 2. Of the 7 villages surveyed, 3 villages (Ignacio Zaragoza, Tierra Santa, and Los Ángeles) continue to cultivate jatropha; 1 other village (Javier López Moreno) also continues to cultivate jatropha, but the area under cultivation is declining; and 3 villages (Doctor Belisario Domínguez, Los Amates, and Niños Héroes) have abandoned jatropha cultivation altogether.

Table 1. Outline of the surveyed villages

\begin{tabular}{|c|c|c|c|c|c|c|}
\hline Municiparity & Village & $\begin{array}{l}\text { Number of } \\
\text { interviewed }\end{array}$ & $\begin{array}{c}\text { Number of } \\
\text { jatropha } \\
\text { growers }\end{array}$ & $\begin{array}{l}\text { Population } \\
\text { of village }\end{array}$ & $\begin{array}{l}\text { Altitude } \\
\text { (m) }\end{array}$ & Date of interview \\
\hline Villa Corzo & Doctor Belisario Domínguez & 11 & 0 & 331 & 735 & Sept. 20, 2012 \\
\hline Villa Corzo & Ignacio Zaragoza & 7 & 14 & 367 & 760 & Sept. 29, 2012 \\
\hline Villa Corzo & Los Amates & 24 & 0 & 182 & 700 & Sept. 19, 2012 \\
\hline Villa Corzo & Tierra Santa & 10 & 10 & 344 & 840 & Oct. $\quad 2,2012$ \\
\hline Villaflores & Los Ángeles & 21 & 65 & 723 & 900 & Sept. 13, 2012 \\
\hline Villaflores & Javier López Moreno & 7 & 7 & $210^{*}$ & $780 *$ & Sept. 27, 2012 \\
\hline La Concordia & Niños Héroes & 8 & 0 & 795 & 600 & Sept. 17,2012 \\
\hline
\end{tabular}


Table 2. Outline of farming and jatropha cultivation

\begin{tabular}{|c|c|c|c|c|c|c|c|c|c|}
\hline \multirow[t]{3}{*}{ Village } & \multicolumn{2}{|c|}{$\begin{array}{c}\text { Farmland } \\
\text { area/house- } \\
\text { hold (ha) }\end{array}$} & \multirow{3}{*}{$\begin{array}{c}\text { Mean } \\
\text { proportion } \\
\text { of planted } \\
\text { area of } \\
\text { corn }(\%)\end{array}$} & \multicolumn{4}{|c|}{$\begin{array}{c}\text { Planted area of } \\
\text { jatropha/household } \\
\text { (ha) }\end{array}$} & \multirow{3}{*}{$\begin{array}{l}\text { Number } \\
\text { of } \\
\text { payments } \\
\text { of } \\
\text { ProArbol }\end{array}$} & \multirow{3}{*}{$\begin{array}{l}\text { Visits by } \\
\text { extension } \\
\text { workers } \\
\text { in } \\
\text { hr/month }\end{array}$} \\
\hline & \multirow{2}{*}{ Mean } & \multirow{2}{*}{$\mathrm{SD}$} & & \multicolumn{2}{|c|}{2008} & \multicolumn{2}{|c|}{2012} & & \\
\hline & & & & Mean & SD & Mean & SD & & \\
\hline Doctor Belisario Domínguez & 21.3 & 16.0 & 23.9 & 6.0 & 72.0 & 0 & - & $1 *$ & 20.0 \\
\hline Ignacio Zaragoza & 22.5 & 30.3 & 31.1 & 5.6 & 4.4 & 5.6 & 4.4 & 0 & 0.2 \\
\hline Los Amates & 14.3 & 8.7 & 31.5 & 4.9 & 3.6 & 0 & - & 0 & 0.7 \\
\hline Tierra Santa & 19.8 & 7.2 & 16.2 & 7.0 & 3.8 & 7.0 & 3.8 & 2 & 4.0 \\
\hline Los Ángeles & 18.0 & 16.3 & 17.8 & 2.7 & 2.1 & 2.7 & 2.1 & 2 & 43.2 \\
\hline Javier López Moreno & 6.4 & 2.5 & 20.3 & 3.3 & 2.5 & 2.0 & 2.0 & 0 & 0.2 \\
\hline Niños Héroes & 15.0 & 11.9 & 52.7 & 4.5 & 5.7 & 0 & - & 0 & 1.7 \\
\hline
\end{tabular}

* After receiving first ProArbol payment, jatropha cultivation was abandoned due to damage by animal pests (gophers). "Visits by extension workers in hr/month" are monthly averages of total hours per month spent by extension workers in each village.

Farmers cited ProArbol payments for jatropha cultivation, the environmental contribution accruing to jatropha cultivation, and the introduction of jatropha as a new cash crop as their reasons for starting to cultivate jatropha. In the villages of Ignacio Zaragoza, Tierra Santa, and Los Ángeles that continue to cultivate jatropha, and in Doctor Belisario Domínguez, where gopher (known locally as tuza) depredation has forced farmers to temporarily abandon jatropha cultivation, the average area of farmland per household stands at 19.7 ha. The average for the villages of Los Amates and Niños Héroes that have abandoned jatropha cultivation, and for Javier López Moreno, where jatropha cultivation has been downsized, is 13.1 ha.

The study by Skutsch et al. (2011) in Chiapas showed that the area of farmland per household for a great many jatropha farmers stood at around 20 ha, a figure that matches the results of our own study of jatropha farmers. Our study shows that while the failure to receive ProArbol payments is also a factor, the fact that the average area of farmland per household for jatropha farmers in villages experiencing problems with jatropha cultivation itself is 13.1 ha suggests that farmers with less than about 20 ha are likely to meet with problems if they attempt to cultivate jatropha. Further research is required to elucidate the causal relationship between total farmland area and the occurrence of problems with jatropha cultivation, and to determine the approximate area of farmland that should be owned by farmers targeted for the promotion of jatropha cultivation so as to ensure sustained cultivation.

\subsection{Factors Impeding the Spread of Jatropha Cultivation}

To analyze the factors impeding the spread of jatropha cultivation, we show questionnaire results regarding reasons for abandoning jatropha cultivation cited by farmers who had done so in Figure 1, and questionnaire results for all farmers regarding the most common problems related to jatropha cultivation in Figure 2.

Failure to receive ProArbol payments and damage caused by gophers to jatropha were cited as reasons for abandoning jatropha cultivation. Pest/disease outbreaks, lack of technical assistance, lack of trust in extension workers, and distrust for the project were cited as problems related to jatropha cultivation.

\subsubsection{ProArbol}

In the villages of Los Amates and Niños Héroes where jatropha cultivation had been abandoned, the direct reason for abandoning cultivation was the failure of farmers to receive ProArbol payments as a result of problems (e.g. less visiting hours of extension workers) in the way that extension workers handled ProArbol payment applications (Table 2). In Javier López Moreno too, farmers failed to receive ProArbol payments as a result of extension worker payment application processing problems and the poor growth shown by jatropha plants, but they continue to cultivate jatropha, albeit on a smaller scale. In the village of Ignacio Zaragoza, problems again occurred in ProArbol application procedures owing to the replacement of 4 extension workers, and the farmers failed to receive payments as a result. The farmers cultivating jatropha in this village harbor a strong distrust for the Chiapas state government's jatropha project, but continue to cultivate jatropha in the hope of selling seeds. 
Since, as mentioned in 3.1, ProArbol payments are one of the main reasons for cultivating jatropha cited by farmers, failure to receive these payments naturally causes farmers to abandon cultivation or downsize cultivation area, and to harbor distrust for extension workers and the project as a whole. As such, failure to make ProArbol payments is a major factor impeding the spread of jatropha cultivation.

\subsubsection{Damage by Animal Pests}

In the village of Doctor Belisario Domínguez where jatropha cultivation had been abandoned, damage caused to jatropha roots by gophers had rendered continued cultivation impossible (Figure 1). Though differing in extent, gopher damage was in fact reported in all villages surveyed for this study. The species causing the damage is suspected to be Geomys bursarius, but more detailed research is required. Since no previous reports of gopher damage to jatropha roots exist, this is thought to be the first such report. In villages other than Doctor Belisario Domínguez too, pest/disease outbreaks of various kinds were reported (Figure 2a). This suggests that failure to act promptly to control pests is likely to impede the further spread of jatropha cultivation.

\subsubsection{Extension Workers}

Extension workers perform the important roles of instructing farmers in jatropha cultivation and handling ProArbol payment application procedures on behalf of jatropha farmers. If ProArbol payments fail to be made as a result of extension worker shortcomings, farmers are likely to abandon jatropha cultivation and harbor distrust for the project as a whole. As such, poorly performing extension workers are a factor impeding jatropha cultivation.

Responses to our questionnaire show that the villages of Ignacio Zaragoza, Javier López Moreno, Niños Héroes and Los Amates have suffered a lack of technical assistance from extension workers (Figure 2b), and that trust for extension workers is at a low level in these villages (Figure 2c). The number of hours spent by extension workers in each of these villages per month was low compared with the villages of Los Ángeles, Doctor Belisario Domínguez, and Tierra Santa, where no such lack of technical assistance was reported (Table 2). These factors impeding the spread of jatropha cultivation result in distrust for the project (Figure 2d).

Basinger et al. (2012) have reported in a study on jatropha cultivation in Mali that the number of visits by extension workers is the most important factor taken into account by farmers when deciding whether to start to cultivate jatropha. Our study of jatropha cultivation at the harvesting stage also revealed that frequent visits by extension workers are an important factor in sustaining jatropha cultivation. As such, bolstering extension worker engagement of farmers would likely play a significant part in encouraging farmers to start cultivating jatropha and ensuring sustained jatropha cultivation.

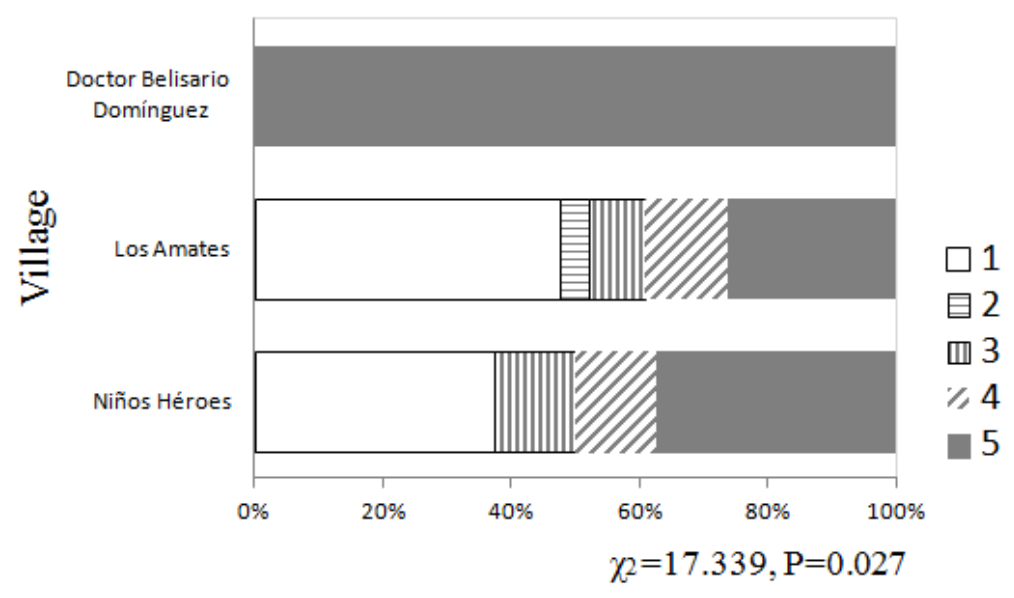

Figure 1. Responses to the questionnaire on damage caused to jatropha by gophers

For cases in which damage by gophers was the sole reason for abandoning jatropha cultivation were given a score of 5 , and cases in which damage by gophers was not a reason for abandoning jatropha cultivation were given a score of 1 . 
(a)

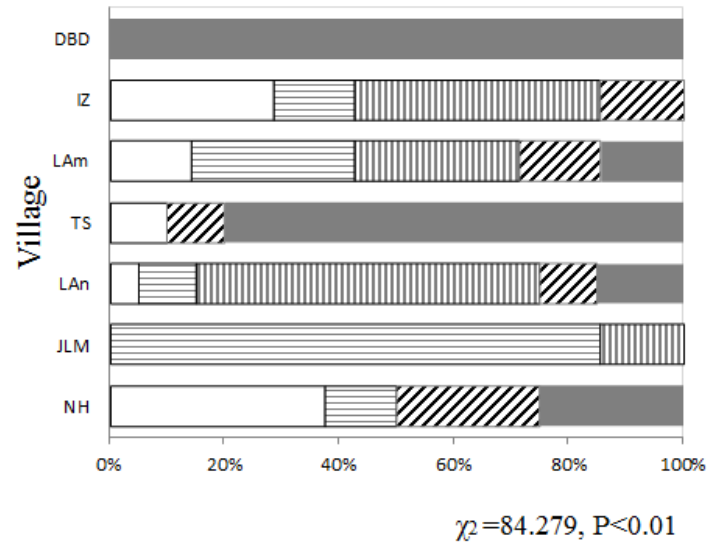

(c)

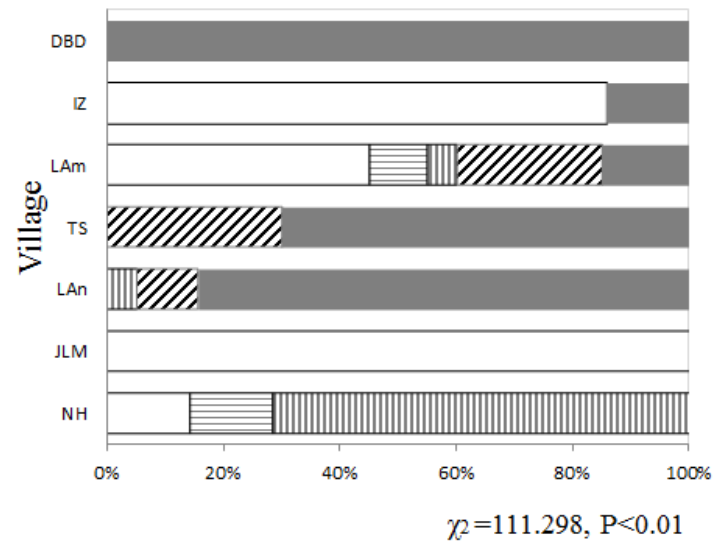

(b)

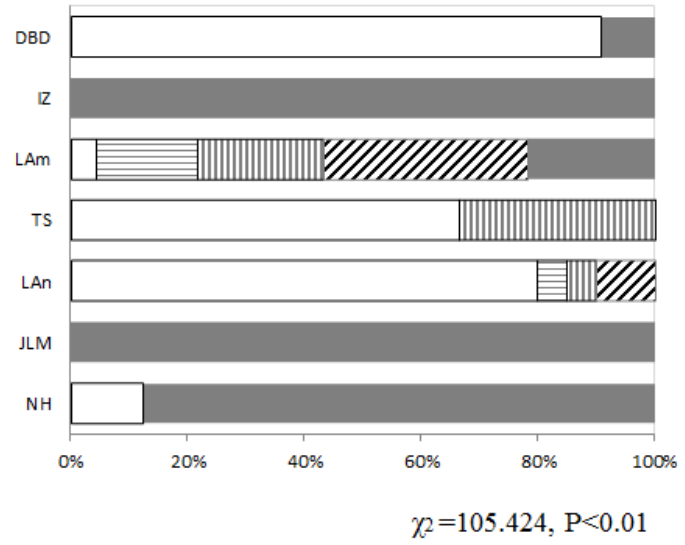

(d)

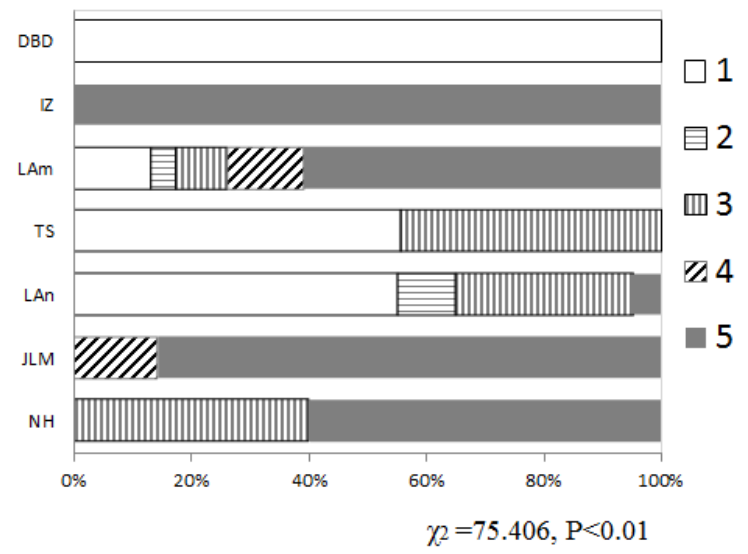

Figure 2. Responses to the questionnaire on (a) Pest/disease outbreak, (b) Lack of technical assistance,

(c) Trust in extension workers, and (d) Distrust for the project

DBD: Doctor Belisario Domínguez, IZ: Ignacio Zaragoza, LAm: Los Amates, TS: Tierra Santa, LAn: Los Ángeles, JLM: Javier López Moreno, NH: Niños Héroes. For "Pest/disease outbreak", cases in which pest damage seriously affected jatropha cultivation were given a score of 5 , and cases in which pest damage was not a problem were given a score of 1. For "Lack of technical assistance", cases in which lack of technical assistance seriously affected jatropha cultivation were given a score of 5 , and cases in which lack of technical assistance was not a problem were given a score of 1 . For "Trust in extension workers", strong trust in extension workers was given a score of 5 , and total lack of trust a score of 1 . For "Distrust for the project", strong distrust for the project was given a score of 5 , and no distrust a score of 1 .

\section{Conclusion and Recommendation}

We conducted this study to ascertain the factors impeding the spread of jatropha cultivation by surveying both farmers who have abandoned jatropha cultivation and those who continue to cultivate jatropha. Our research revealed the existence of two causes behind the abandonment of jatropha cultivation by farmers-namely, the failure of farmers to receive ProArbol payments as financial assistance for jatropha cultivation, and damage to jatropha roots by gophers. These two factors directly impede the continued cultivation of jatropha. Other pest/disease outbreaks, lack of technical assistance, lack of trust in extension workers, and distrust for the project are also issues affecting jatropha cultivation.

We make the following recommendations for eliminating the factors impeding the spread of jatropha cultivation on family farms in Chiapas.

Firstly, to ensure that proper ProArbol payment application procedures are followed, we recommend training in ProArbol application procedures for extension workers, as well as bolstering the engagement of jatropha farmers by extension workers. 
Secondly, with regard to pest damage, we recommend that urgent consideration be paid to means of controlling gophers, the most serious cause of pest damage. Also, in view of the fact that pest/disease damage is rising, we see a need to also consider longer-term pest control measures, including training extension workers in pest control techniques.

\section{Acknowledgements}

We would like to express our gratitude to Antolín Morales Vásquez, Chairman of USB, for the many different ways in which he assisted our research, and to the extension workers and farmers who cooperated with us for this study.

\section{References}

Arellanes-Caballero, R. A. (2008). Programa Bioenergéticos Chiapas, 1 Congreso Internacional de Biocombustibles. Instituto de Bioenergéticos y Energías Alternativas del Estado de Chiapas. Guadalajara (in Spanish). Retrieved November 5, 2012, from http://www.biocombustibles.gob.mx/8may/insumos/Sal\%C3\%B3n\%20de\%20Conferencias\%20Dos/Rafael \%20Arellanes\%20-\%20Comision\%20Estatal\%20de\%20Bioeneg\%C3\%A9ticos\%20Chiapas.ppt

Axelsson, L., Franzén, M., Ostwald, M., Berndes, G., \& Ravindranath, N. H. (2011). Performance of jatropha biodiesel production and its environmental and socio-economic impacts - a case study in Southern India, World Renewable Energy Congress, Linköing, Sweden.

Basinger, M., Chen, J., Jeffrey-Coker, F., Rodriguez-Sanchez, F. S., Singer, T., \& Mod, V. (2012). Jatropha adoption: a statistical observational study of factors influencing Malian farmers' decision to grow Jatropha, Agroforestry Systems, 84, 59-72. http://dx.doi.org/10.1007/s10457-011-9426-z

Brittaine, R., \& Lutaladio, N. (2010). Jatropha: a smallholder bioenergy crop. The potential for pro-poor development, Integrated Crop Management, Vol. 8, FAO, Rome.

Gobierno del Estado de Chiapas. (2007). Plan de Desarrollo Chiapas Solidario 2007-2012 Eje 3 Chiapas competitivo y generador de oportunidades (in Spanish). Retrieved November 5, 2012, from http://ordenjuridico.gob.mx/Publicaciones/CDs2011/CDPaneacionD/pdf/6.\%20EJE\%203.pdf

Gobierno del Estado de Chiapas. (2012a). En Chiapas 1a Planta Extractora de Aceite de Jatropha del país (in Spanish). $\quad$ Retrieved November $\quad 5, \quad 2012, \quad$ from http://www.chiapas.gob.mx/prensa/boletin/en-chiapas-a-planta-extractora-de-aceite-de-jatropha-del-pais

Gobierno del Estado de Chiapas. (2012b). Toda una realidad proyecto Bioenergéticos (in Spanish). Retrieved November 5, 2012, from http://www.secretariadelcampo.gob.mx/plantilla/ejemplos/evento/Biodiesel

Green fuels. (2012). State of Chiapas, Mexico. Retrieved December 6, 2012, from http:/greenfuels.co.uk/case-studies/mexico-biodiesel/

Heller, J. (1996). Physic nut. Jatropha curcas L. Promoting the conservation and use of underutilized and neglected crops. 1, Institute of Plant Genetics and Crop Plant Research, Gatersleben/International Plant Genetic Resources Institute, Rome.

Ruíz-Valdiviezo, V. M., Luna-Guido, M., Galzy, A., Gutiérrez-Miceli, F. A., \& Dendooven, L. (2010). Greenhouse gas emissions and $\mathrm{C}$ and $\mathrm{N}$ mineralization in soils of Chiapas (México) amended with leaves of Jatropha curcas L. Applied Soil Ecology, 46(1), 17-25. http://dx.doi.org/10.1016/j.apsoil.2010.06.002

Skutsch, M., De los Rios, E., Solis, S., Riegelhaupt, E., Hinojosa, D., Gerfert, S., ... Masera, O. (2011). Jatropha in Mexico: Environmental and Social Impacts of an Incipient Biofuel Program. Ecology and Society, 16(4), 11. http://dx.doi.org/10.5751/ES-04448-160411

Valero-Padilla, J., Cortina-Villar, H. S., \& Vela-Coiffier, M. P. (2011). El proyecto de biocombustibles en Chiapas: experiencias de los productores de piñón (Jatropha curcas) en el marco de la crisis rural. Estudio Sociales, 19(38), 120-144 (in Spanish). Retrieved November 5, 2012, from http://www.redalyc.org/src/inicio/ArtPdfRed.jsp?iCve=41719205005

Vanegas-Cubillos, M. C. (2012). Productive Organizations and Development: Jatropha curcas production in Chiapas, southern Mexico, Master Thesis, Wageningen University. The Netherlands. Retrieved December 6, 2012, from http://edepot.wur.nl/221834

Zamarripa-Colmenero, A., Ruíz-Cruz, P. A., Solís-Bonilla, J. L., Martínez-Herrera, J., Olivera-De los Santos A., \& Martínez-Valencia B. (2009). Biocombustibles: Perspectivas De Producción De Biodiesel A Partir De Jatropha curcas L. En El Trópico De México, INIFAP, Tuxtla Chico (in Spanish). 